\title{
Characterization of ternary complexes of meloxicam-HP $\beta C D$ and PVP or L-arginine prepared by the spray-drying technique
}

\author{
HODA A. EL-MARADNY ${ }^{1}$ \\ SANA A. MORTADA ${ }^{1}$ \\ OLA A. KAMEL ${ }^{2}$ \\ AHMED H. HIKAL ${ }^{2}$ \\ ${ }^{1}$ Department of Industrial Pharmacy \\ Faculty of Pharmacy \\ University of Alexandria \\ 2 Amriya Pharmaceutical Industry \\ Alexandria, Egypt
}

Ternary complexes of meloxicam (ME) (a poorly water soluble anti-inflammatory drug) with hydroxypropyl- $\beta$ -cyclodextrin (HP $\beta C D$ ) and either a hydrophilic polymer, namely, polyvinyl pyrrolidone (PVP) or a basic amino acid such as L-arginine, were prepared by the spray-drying technique. The solubilizing efficiency, physical properties and dissolution behaviour of each ternary system of ME-HP $\beta C D$ with either PVP or L-arginine were compared with those of the corresponding binary system of ME-HP $\beta C D$. Tablets compressed from the ternary system of ME-HP $\beta C D$-L-arginine were compared with plain and commercial tablets. Phase solubility experiments suggested the formation of an inclusion complex of $A_{L}$ type. Ternary system of ME-HP $\beta C D$-L-arginine exhibited a stability constant 30.3 times higher than the binary system of ME-HP $\beta C D$, while the ternary system of ME-HP $\beta C D-$ -PVP increased the stability constant 2.2 times only. The prepared complexes were characterized by scanning electron microscopy, differential scanning calorimetry and infra red spectroscopy. Ternary solid complexes indicated the presence of strong interactions between the components. The dissolution behaviour of ME from different ternary complexes was higher than its dissolution from the binary system. Tablets compressed from ternary complexes of ME-HP $\beta C D$-L-arginine highly improved drug release compared to plain and commercial tablets.

Keywords: meloxicam, hydroxypropyl- $\beta$-cyclodextrin, polyvinyl pyrrolidone, L-arginine, spray-drying technique

Cyclodextrins and their derivatives play an important role in improving the therapeutic efficacy of drugs with poor solubility and/or stability problems. They are capable of alleviating the undesirable properties of drug molecules through the formation of inclusion complexes (1). Hydroxypropyl- $\beta$-cyclodextrin (HP $\beta C D$ ) is mainly selected for its higher solubility than other cyclodextrins and this generally results in more extensive solubilization ability toward lipophilic molecules, with a good safety profile (2).

\footnotetext{
*Correspondence, e-mail: hodaelmaradny@yahoo.com
} 
However, the exploitation of cyclodextrin properties in the pharmaceutical area is hindered by problems such as high molecular mass, rather high cost and potential parenteral toxicity (3). Strengthening the complexation and solubilization efficacy of cyclodextrins is a possible tool to reduce their amount in pharmaceutical formulations. Among the strategies proposed toward this aim is the addition of suitable auxiliary substances, which can be a valuable approach to increase cyclodextrin solubilizing capacity by multi-component complex formation (4-6).

It has been shown that certain low molecular mass acids or hydroxyacids can strongly enhance the cyclodextrin solubilizing power toward basic drugs, as a result of the combined effect of salt formation and inclusion complexation (7). For instance, it has been reported that the addition of small amounts of polyvinyl pyrrolidone (PVP) to the naproxen-HP $\beta C D$ system improved the complexing and solubilizing efficiencies of HP $\beta C D$ (8). Likewise, solubilization and dissolution of celecoxib (9) and vinpocetine (10) from $\mathrm{HP} \beta \mathrm{CD}$ were also increased in the presence of hydrophilic polymers.

The combined effect of HP $\beta C D$ and a series of amino acids to test their effectiveness as ternary components on the enhancement of the drug aqueous solubility was investigated (11). L-arginine was the best candidate among many amino acids; it showed the largest increase in the intrinsic solubility of naproxen and a peculiar synergistic effect when used in combination with $\mathrm{HP} \beta C D$ (12).

Meloxicam (ME), (4-hydroxy-2-methyl- $N$-\{5-methyl-2-thiazolyl $\}-H-1,2$ benzothiazine-3-caboxamide 1,1-dioxide), is a potent nonsteroidal anti-inflammatory drug. It is practically insoluble in water $\left(12 \mu \mathrm{g} \mathrm{mL}^{-1}\right)$. Its poor solubility and wettability leads to difficulties in formulating oral and parenteral solutions and thereby variations in bioavailability.

In the present work, it seemed of interest to investigate the role of PVP (hydrophilic polymer) and L-arginine (amino acid) in improving the dissolution properties of ME and its bioavailability. Binary and ternary complexes were prepared by spray-drying technique.

\section{EXPERIMENTAL}

\section{Materials}

Meloxicam (Sun Pharma Ltd, India), polyvinyl pyrrolidone k30 (BASF, Germany), hydroxypropyl $\beta$-cyclodextrin (Roquette, France), L-arginine (Sigma Chemical Company, USA), croscarmellose sodium (Acdisol, FMC Biopolymer, USA), spray-dried lactose (Porculsdomo, USA), magnesium stearate (Winlap, UK), commercial 15 mg meloxicam tablet (Mobic ${ }^{\circledR}$, Boehringher, Germany) were used. All other reagents and solvents were of analytical grade.

\section{Solubility studies}

Known excess amounts of ME (50 mg) were added to $20 \mathrm{~mL}$ of aqueous solutions of various concentrations of $\mathrm{HP} \beta C D$ ranging between 1 and $10 \%(\mathrm{~m} / \mathrm{V})$. The suspensions were vigorously shaken in a shaking water bath at $25 \pm 0.5^{\circ} \mathrm{C}$ for 2 days. After equilibrium was attained, saturated solutions were centrifuged and the supernatants were filtered through a $50-\mu \mathrm{m}$ Millipore filter. After suitable dilution, samples were assayed for drug 
H. A. El-Maradny et al.: Characterization of ternary complexes of meloxicam-HPßCD and PVP or L-arginine prepared by the spraydrying technique, Acta Pharm. 58 (2008) 455-466.

concentration using a UV spectrophotometer (Varian-Cary 100 Bio, Shimadzu, Australia) at $\lambda_{\max }$ of $360 \mathrm{~nm}$. To establish the effect of auxiliary polymers (PVP or L-arginine) on the solubility diagram, each was added separately at a concentration of $0.1 \%(\mathrm{~m} / \mathrm{V})$ to a suspension of ME-HP $\beta C D$ and then allowed to equilibriate at $25 \pm 0.5{ }^{\circ} \mathrm{C}$ for 2 days. Meloxicam solubility was investigated using the previously described method. Each solubility experiment was performed in triplicate.

\section{Preparation of solid complexes}

Aqueous equimolar mixtures of either binary ME-HP $\beta C D$ or ternary ME-HP $\beta C D-$ $-0.1 \%$ PVP and ME-HP $\beta$ CD-0.1\% L-arginine were prepared using a nozzle type spray dryer (Büchi Labortechnik AG, Switzerland). For the binary complex, $1.2 \mathrm{~g}$ of meloxicam and $4.8 \mathrm{~g}$ of $\mathrm{HP} \beta \mathrm{CD}$ were dispersed in $400 \mathrm{~mL}$ water. The solutions were stirred for $24 \mathrm{~h}$ at ambient temperature. In the case of ternary complexes, the same equimolar amounts of meloxicam and HP $\beta C D$ were dispersed in $0.1 \%$ PVP or $0.1 \%$ L-arginine. All aqueous mixtures were delivered separately to the nozzle at a flow rate of $5 \mathrm{~mL} \mathrm{~min}^{-1}$ by a peristaltic pump and then spray-dried using a spray dryer with atomization pressure of $1.8 \mathrm{~kg}$ $\mathrm{cm}^{-2}$. Inlet and outlet temperatures were maintained at 120 and $60^{\circ} \mathrm{C}$, respectively. Samples were collected and stored in a desiccator kept at $25^{\circ} \mathrm{C}$ for further analyses.

\section{Characterization of solid complexes}

Scanning electron microscopy (SEM). - The samples were fixed on an abrass stub using double-sided tape and then gold coated in vacuum with a sputter coater JSM-5300, Joel, Japan. The excitation voltage was $15 \mathrm{kV}$ and pictures were taken at 3500-fold magnification.

Particle size analysis. - Particle size of ME, binary ME-HP $\beta C D$ and ternary complexes with either PVP or L-arginine were determined within the range of $0.04-500 \mu \mathrm{m}$ using a laser diffractometer (Cilas L-100, France).

Differential scanning calorimetry (DSC). - Calorimetric responses of pure samples, physical mixtures and binary and ternary solid complexes were measured using a DSC instrument (Perkin Elmer DSC6, USA. The thermal behaviour was studied by heating 3-5 mg of each sample in aluminum crimped pans under nitrogen gas flow (20 mL min $\left.{ }^{-1}\right)$ at a scanning rate of $10{ }^{\circ} \mathrm{C} \mathrm{m^{-1 }}$ over a temperature range of $30-300{ }^{\circ} \mathrm{C}$. All determinations were made in triplicate.

Infrared identification (IR). - IR spectra of pure samples, physical mixtures, binary and ternary solid complexes were recorded on an IR multiscope spectrophotometer (Perkin Elmer 1600, USA). Each sample ( $3 \mathrm{mg}$ ) was mixed with dry potassium bromide and then examined over the wave number range of 3500-1000 $\mathrm{cm}^{-1}$. All determinations were made in triplicate and compared with the spectra of physical mixtures and pure materials.

\section{Preparation and testing of tablets}

Spray-dried equimolar ternary solid complexes of ME-HP $\beta C D$ with $0.1 \%$ L-arginine were compressed into tablets using a 9-mm flat faced punch tablet machine (single punch tablet press, Erweka, Apparatebau, Germany). An accurate mass of solid complex (84\%) equivalent to $15 \mathrm{mg}$ drug was well mixed with 5\% Na-croscarmellose, 1\% Mg-stearate 
H. A. El-Maradny et al.: Characterization of ternary complexes of meloxicam-HP $\beta C D$ and PVP or L-arginine prepared by the spraydrying technique, Acta Pharm. 58 (2008) 455-466.

and $10 \%$ spray-dried lactose. The mixture was then compressed into tablets (100 mg each) of $60-80 \mathrm{~N}$ hardness. Physical properties of the tablets were measured. Friability was determined using a Roche Friabilator (Voss Instrument Ltd, UK) with 20 tablets in 4 minutes (100 revolutions). The disintegration time was determined for 6 tablets with a USP disintegration apparatus (Erweka, ZT43. Heusenstamm, Germany) at $37 \pm 0.5{ }^{\circ} \mathrm{C}$ in water (13).

A plain meloxicam tablet $(100 \mathrm{mg})$ equivalent to a $15-\mathrm{mg}$ drug with the same excipients was compressed as described before.

\section{Dissolution rate studies}

USP XXI Hanson dissolution apparatus type II was used to monitor the drug release according to $\mathrm{BP}$ (13). Accurate weights of either binary mixtures of ME-HP $\beta C D$ or ME-HP $\beta$ CD-0.1\% L-arginine ternary mixture equivalent to a 15-mg drug were added to 900 $\mathrm{mL}$ of phosphate buffer $\mathrm{pH} 7.4 \mathrm{kept}$ at $37 \pm 0.5^{\circ} \mathrm{C}$ and stirred at $100 \mathrm{rpm}$ using a paddle. Samples of $10 \mathrm{~mL}$ were withdrawn at different time intervals up to $60 \mathrm{~min}$. The volume taken was replaced by an equal volume of pre-warmed dissolution medium. The samples were filtered through a $50-\mu \mathrm{m}$ Millipore filter and spectrophotometrically analyzed for drug concentration at $\lambda_{\max } 360 \mathrm{~nm}$. In the case of the tablet compressed from ME -HP $\beta C D-0.1 \%$ L-arginine ternary mixture and commercial tablet, the same dissolution conditions were applied as above using a basket instead of a paddle. The experiment was repeated at least three times.

Data obtained from in vitro release studies were fitted to various kinetic equations. The kinetic models used were zero order, first order and Higuchi equations.

\section{RESULTS AND DISCUSSION}

\section{Solubility studies}

Phase solubility diagrams of ME in the binary system with HP $\beta C D$ and ternary system with HP $\beta C D$ and either $0.1 \%(\mathrm{~m} / \mathrm{V})$ PVP or $0.1 \%(\mathrm{~m} / \mathrm{V})$ L-arginine in aqueous soluions at $25{ }^{\circ} \mathrm{C}$ are illustrated in Figure 1 . Solubility diagrams exhibit $\mathrm{A}_{\mathrm{L}}$ type according to the Higuchi and Connors classification (14), showing a linear increase of drug solubility upon increasing HP $\beta C D$ concentration and indicating the formation of soluble complexes. The ratio between the slopes of the phase solubility curves of ternary and binary systems, as an index of the relative solubilizing efficiency, was 2.2 for PVP and 4.6 for L-arginine, confirming the greater effectiveness of the ternary system. The apparent stability constants for binary ME-HP $\beta C D$, ternary ME-HP $\beta C D$ with either PVP or L-arginine were 227.92, 496.88, 6915.1 $\mathrm{mol}^{-1}$, respectively. Moreover, an increase of ME-HPßCD interaction was observed in the ternary system, as indicated by the increase of the stability constant values $\left(K_{\mathrm{c}}\right)$ by about 2.2 fold and 30.3 fold for PVP and L-arginine compared to the corresponding binary complex, respectively. This enhancement may be related to the molecular interaction based solubilization of the amorphous form of the drug and interactions in the solution state between the components of amorphous molecular dispersions (15). 


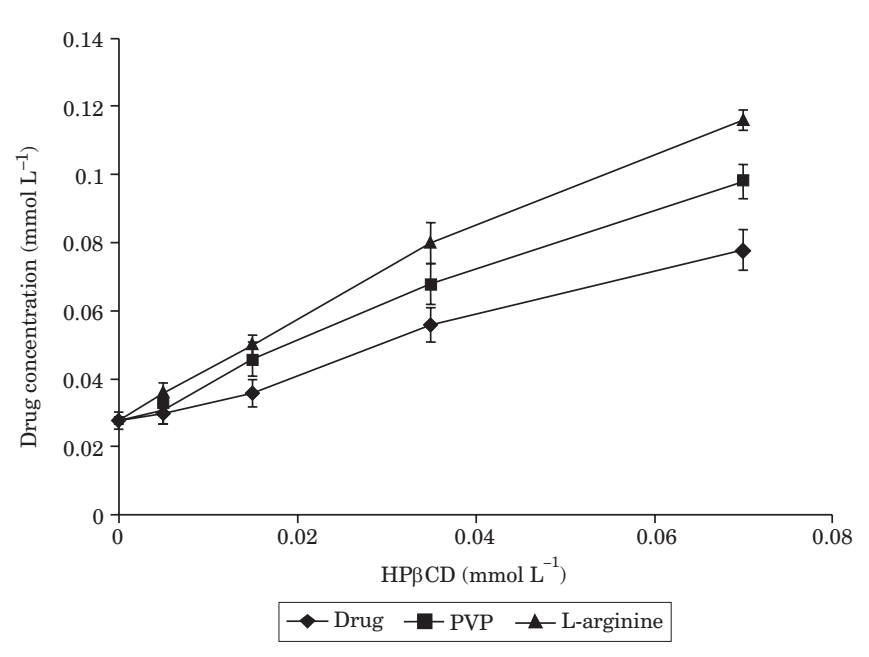

Fig. 1. The effect of HPBCD concentration on meloxicam solubility in the presence of either $0.1 \%(\mathrm{~m} / \mathrm{V})$ of PVP or $0.1 \%(m / V)$ L-arginine (mean $\pm \mathrm{SD}, n=3)$.

According to the results, complexing with L-arginine afforded the most stable complex and the better performance of that complex will allow reduction in the amount of cyclodextrin needed to solubilize a given amount of drug (16).

\section{Solid state studies}

The particular behaviour of ME either in binary or ternary systems appeared as irregular crystals with a particle size of $6.76 \mu \mathrm{m}$, whereas HP $\beta C D$ particles (Fig. 2b) had a parallelogram shape. For spray-dried binary (Fig. 2c) or ternary systems (Fig. 2d and e), dramatic changes in particle size and shape were noticed. The particle size was 3.85, 2.52 and $1.68 \mu \mathrm{m}$ for ME-HP $\beta C D$ binary, ternary with PVP or L-arginine spray dried complexes, respectively. This is probably due to the formation of new amorphous spherical particles with different morphology, indicating the formation of an inclusion complex. Moreover, ternary system SEM showed relatively uniform small-sized spherical hollow spheres, especially when using L-arginine (Fig. 2e).

DSC technique draws attention to the interaction between the drug and excipients in its formulation. When guest molecules are included in cyclodextrin cavities, their melting, boiling and sublimation points shift to different temperature or disappear (17). DSC thermograms of ME, HP $\beta C D, P V P$, L-arginine and their binary and ternary physical and spray dried systems are represented in Fig. 3. DSC analysis indicated the crystalline state of ME with a characteristic endothermic fusion peak at $257.4^{\circ} \mathrm{C}\left(\Delta H=89.74 \mathrm{~J} \mathrm{~g}^{-1}\right)$ corresponding to its melting temperature. A broad endothermic band at $120{ }^{\circ} \mathrm{C}$ was observed for the amorphous $\mathrm{HP} \beta C D$, which was related to the loss of water molecule, i.e., dehydration process. In the case of PVP, a peak at $75.7^{\circ} \mathrm{C}$ was assignable to water evaporation, whereas, L-arginine showed three distinct endotherms peaking at 101.2, 223.06 and 
a)

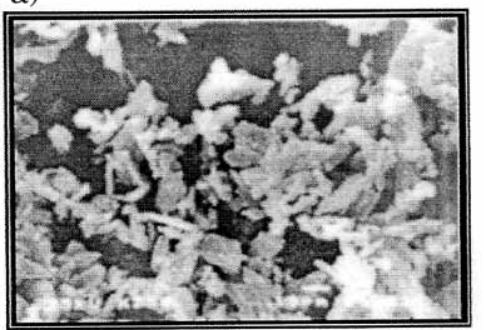

c)

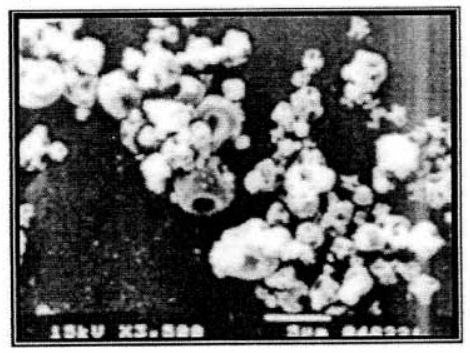

b)

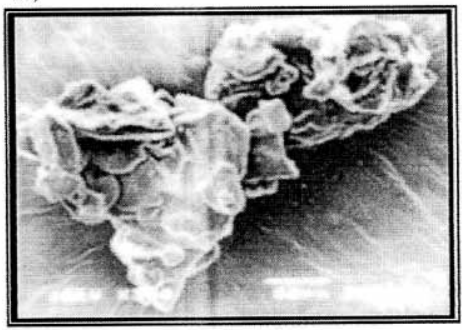

d)

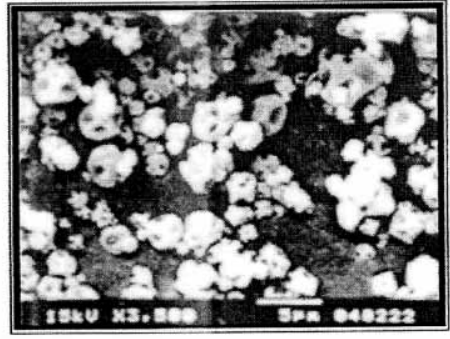

e)

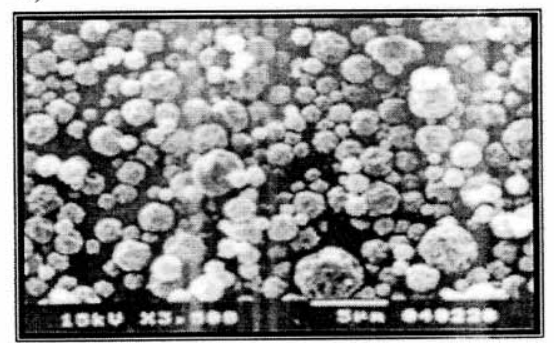

Fig. 2. Scanning electron photomicrographs of: a) meloxicam, b) HP $\beta C D$, c) binary spray-dried complex, d) ternary complex with $0.1 \%(m / V)$ PVP and e) ternary complex with $0.1 \%(m / V)$ L-arginine.

$238.5^{\circ} \mathrm{C}$, attributable to water loss from a small portion of arginine $2 \mathrm{H}_{2} \mathrm{O}$, melting with decomposition of anhydrous arginine, and total decomposition of the melt. Thermograms of binary and ternary physical mixtures showed superposition of their parent products endotherms. This indicated a partial loss of crystallinity and partial amorphization and/or complexation within the HP $\beta C D$ matrix. Thermogram of the ME-HP $\beta C D$ binary system revealed that the disappearance of peak transition endotherm was due to the formation of amorphous aggregates, where it was impossible to differentiate the two components. Thermal behaviour of solid ternary systems was different. For the ternary complex with PVP, marked broadening of peak and reduction intensity of ME fusion endotherm were observed. This may be attributed to the transformation of drug particles from crystalline to amorphous form. For the ternary complex with L-arginine, the peak disappeared, which 


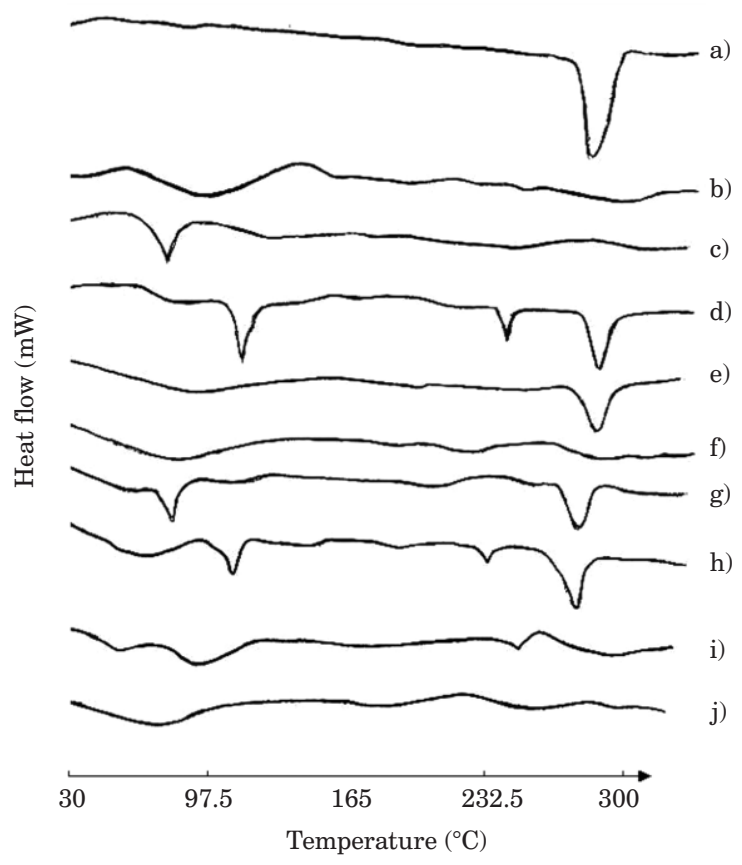

Fig. 3. DSC thermograms of: a) meloxicam, b) HP $\beta C D$, c) PVPK30, d) L-arginine, e) meloxicam-HP $\beta C D$ physical mixture, f) meloxicam $-\mathrm{HP} \beta C \mathrm{CD}$ spray-dried binary complex, g) meloxicam-HP $\beta C D-P V P$ physical mixture, h) meloxicam-HP $\beta C D$-L-arginine physical mixture, i) meloxicam-HP $\beta C D-P V P$ spray-dried ternary complex and $\mathrm{j}$ ) meloxicam-HP $\beta C D$-L-arginine spraydried ternary complex.

could be explained on the basis of a major interaction between the drug and HP $\beta C D$ in the presence of L-arginine.

IR spectra for pure components and their binary and ternary complexes are shown in Fig. 4. The spectrum of ME showed characteristic bands attributable to different group vibrations: $1630 \mathrm{~cm}^{-1}$ for the aromatic nucleus and $2630 \mathrm{~cm}^{-1}$ for the stretching of amide carbonyl and stretching of the $-\mathrm{SO}_{2} \mathrm{NH}$ group. The IR spectra of HP $\beta \mathrm{CD}$ showed absorption bands at $3414 \mathrm{~cm}^{-1}$ for stretching vibrations of $\mathrm{NH}$ and $\mathrm{OH}, 2933 \mathrm{~cm}^{-1}$ for $\mathrm{CH}$ stretching vibrations and $1164 \mathrm{~cm}^{-1}$ and $1083 \mathrm{~cm}^{-1}$ for CO stretching vibration. Typical bands of ME were still discernable and did not show any shift in IR spectra in any binary or ternary physical mixtures since they correspond to a superposition of their parent components. However, in the IR spectrum of binary spray-dried complex, the characteristic band of the drug, especially at $1709 \mathrm{~cm}^{-1}$ attributed to $\mathrm{C}=\mathrm{O}$, shifted and reduction of intensity was observed. The amide $\mathrm{NH}$ stretching vibration could not be detected, indicating a strong interaction between ME and the hydroxyl group of $\mathrm{HP} \beta \mathrm{CD}$, whereas the spectrum of ternary complexes exhibited great absorption at $1660 \mathrm{~cm}^{-1}$, which presumably masked possible shifts of the drug carbonyl group stretching. This dramatic change was probably related to the formation of intramolecular hydrogen bonds between the guest and host molecules (18). It seems that when the carbonyl group is joined by hydrogen bonds, the stretching band is shifted to lower frequency due to the weakening of the carbonyl radical double bond. This change also indicates that the vibration of the guest molecule (drug) is restricted due to the formation of an inclusion complex $(19,20)$. 
Fig. 4. IR spectra of: a) meloxicam, b) $\mathrm{HP} \beta C D$, c) PVPK30, d) L-arginine, e) meloxicam-HP $\beta C D$ physical mixture, f) meloxicam-HP $\beta C D$ spray-dried binary complex, g) meloxicam-HP $\beta C D-P V P$ physical mixture, h) meloxicam-HP $\beta C D$-L-arginine physical mixture, i) meloxicam-HP $\beta C D$ -PVP spray-dried ternary complex and j) meloxicam-HP $\beta C D$-L-arginine spray-dried ternary complex.

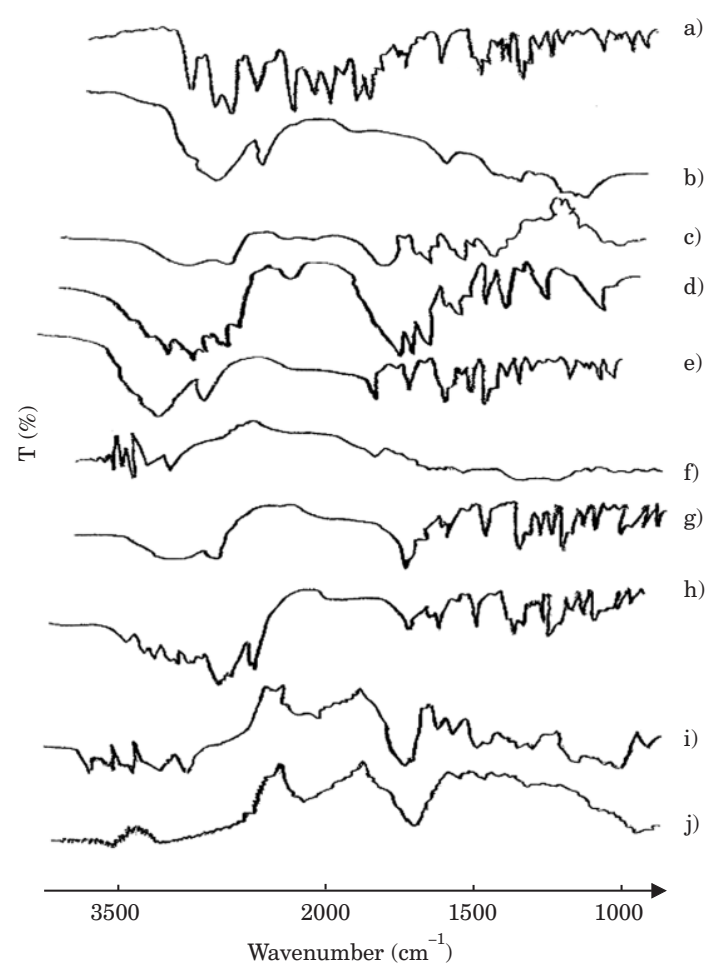

\section{Dissolution studies}

The ME release profiles through binary and ternary powder complexes prepared by the spray-drying technique are illustrated in Fig. 5a. Increase in the dissolution rate was recorded for solid complexes compared to the pure drug. It can be assumed that, in the early stages of the dissolution process, HP $\beta C D$ molecules will operate locally in the hydrodynamic layer surrounding the drug particles. This action resulted in the in situ inclusion process which produced a rapid increase of the amount of dissolved drug (21).

Moreover, ternary systems, indeed, demonstrated significantly better drug dissolution rates than the corresponding binary systems. This is in agreement with Mora et al. (22). In addition, the data revealed that the ternary complex with L-arginine showed a faster dissolution rate than that with PVP. The rank order of improvement in dissolution properties of ME is: ternary complex with L-arginine $>$ ternary complex with PVP $>$ binary mixture. The synergistic effect of L-arginine is due to the potential ability of the basic amino acid to simultaneously interact both with cyclodextrin (via hydrogen bonding) and the drug (via electrostatic interactions and salt formation) (23).

On the basis of these results, the ternary powder mixture with L-arginine was compressed into tablets for further investigations. Compressed tablets exhibited low friability $(0.2 \pm 0.03 \%)$ with a disintegration time of less than $5 \mathrm{~min}$. The drug content was $14.87 \mathrm{mg}$ with drug loading of $99.1 \pm 0.1 \%$. The dissolution profiles of these compressed 
H. A. El-Maradny et al.: Characterization of ternary complexes of meloxicam-HP $\beta C D$ and PVP or L-arginine prepared by the spraydrying technique, Acta Pharm. 58 (2008) 455-466.
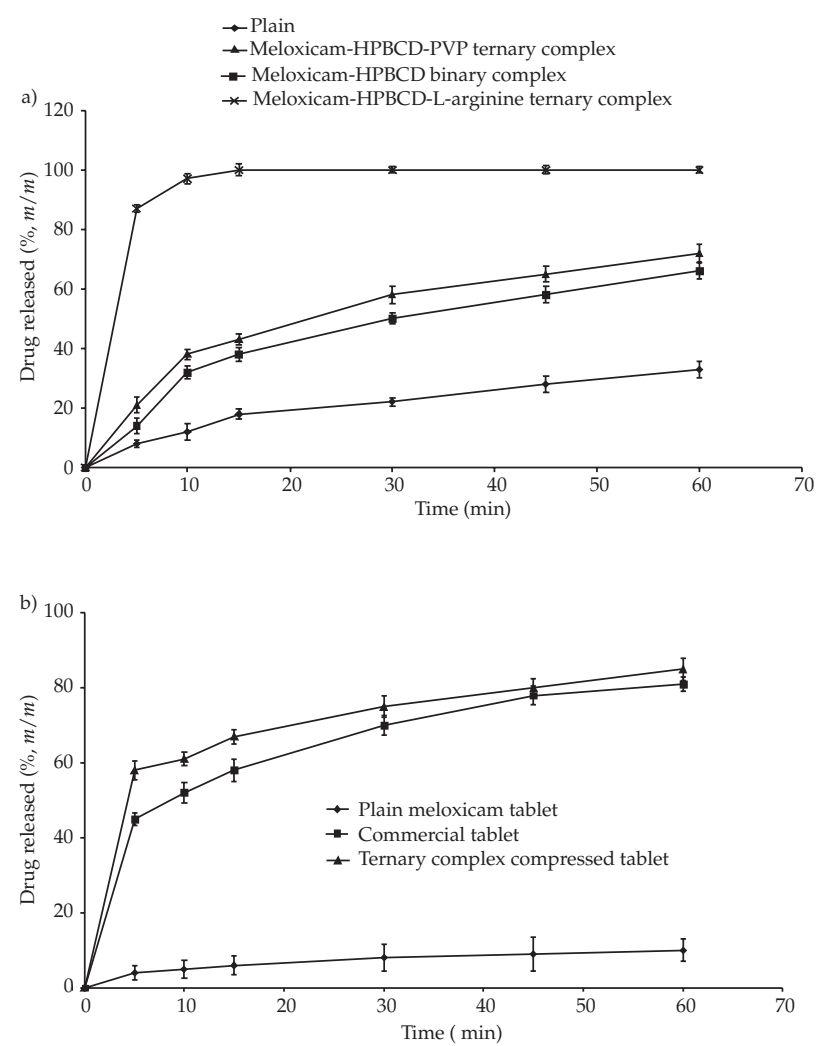

Fig. 5. Dissolution rate profiles of: a) binary and ternary complexes powders, b) prepared tablets of plain meloxicam, ternary complex meloxicam-HPBCD-L-arginine and commercial tablets (mean \pm $\mathrm{SD}, n=3)$.

tablets, compared to plain ME tablets and commercial ones, in phosphate buffer $\mathrm{pH} 7.4$ are illustrated in Fig. 5b. Tablets compressed from the ternary complex with L-arginine showed superior dissolution properties compared to ME tablets and commercial ones, since $74 \%$ of drug was released after $15 \mathrm{~min}$ from the ternary complex compared to the $60 \%$ of the commercial tablet.

The release kinetic studies revealed that the dissolution pattern of ME from all the studied formulations and the commercial tablet followed a first-order dissolution pattern (Table I). 
H. A. El-Maradny et al.: Characterization of ternary complexes of meloxicam-HP $\beta C D$ and PVP or L-arginine prepared by the spraydrying technique, Acta Pharm. 58 (2008) 455-466.

Table I. Release kinetics of ME from different spray dried powders and compressed tablets

\begin{tabular}{|c|c|c|c|c|c|c|c|c|}
\hline \multirow[b]{2}{*}{ Order } & \multicolumn{6}{|c|}{ Spray-dried powder } & \multicolumn{2}{|c|}{ Compressed tablet } \\
\hline & $\begin{array}{c}\text { Kinetic } \\
\text { parameter }\end{array}$ & Drug & $\begin{array}{l}\text { Drug- } \\
-\mathrm{HP} \beta C D\end{array}$ & $\begin{array}{c}\text { Drug-HP } \beta C D- \\
\text {-PVP }\end{array}$ & $\begin{array}{l}\text { Drug-HP } \beta C D- \\
\text { L-Arginine }\end{array}$ & Drug & $\begin{array}{c}\text { Drug-HPBCD } \\
\text { L-Arginine }\end{array}$ & - Commercial \\
\hline \multirow{2}{*}{ Zero } & $k$ & 0.495 & 0.988 & 1.043 & 0.884 & 0.139 & 0.941 & 0.991 \\
\hline & $r$ & 0.958 & 0.929 & 0.912 & 0.532 & 0.908 & 0.735 & 0.821 \\
\hline \multirow{2}{*}{ First } & $k$ & -0.003 & -0.007 & -0.009 & -0.062 & -0.001 & -0.011 & -0.010 \\
\hline & $r$ & 0.973 & 0.974 & 0.971 & 0.927 & 0.915 & 0.902 & 0.953 \\
\hline \multirow{2}{*}{ Higuchi } & $k$ & 4.278 & 8.744 & 9.406 & 10.317 & 1.261 & 9.49 & 9.501 \\
\hline & $r$ & 0.996 & 0.957 & 0.969 & 0.746 & 0.991 & 0.893 & 0.946 \\
\hline
\end{tabular}

\section{CONCLUSIONS}

This study has demonstrated the possibility of markadly improving the dissolution performance of meloxicam by its complexation with $\mathrm{HP} \beta C D$ in the presence of auxiliary substances such as PVP and L-arginine using the spray-drying technique. L-arginine, as a ternary substance, showed a more pronounced effect on the enhancement of aqueous solubility and a faster release drug rate than the ternary complex with PVP. Therefore, the presence of L-arginine in the ternary complex of ME with HP $\beta C D$ can be a good strategy toward reducing the amount of HP $\beta C D$ in pharmaceutical formulations. Moreover, ternary spray-dried ME-HP $\beta C D$-L-arginine appears to be the most valuable product for developing fast-release meloxicam formulations, which can be particularly useful in treatment of all clinical conditions requiring quick pain relief.

\section{REFERENCES}

1. J. Kang, V. Kumar, D. Yang, P. R. Chowdhury and R. J. Hohl, Cyclodextrin complexation: Influence on the solubility, stability and cytotoxicity of camptothecin, an antineoplastic agent, Eur. J. Pharm. Sci. 15 (2002) 163-170; DOI: 10.1016/s0928-0987(01)00214-7.

2. A. Miro, F. Quaglia, L. Giannini, B. Cappello and M. I. La Rotonda, Drug/cyclodextrin solid systems in desiging hydrophilic matrices: A strategy to modulate drug delivery rate, Curr. Drug Deliv. 3 (2006) 373-378; DOI: 10.2174/156720106778 558994.

3. T. Loftsson and M. Brewster, Pharmaceutical applications of cyclodextrins. I. Drug solubilization and stabilization, J. Pharm. Sci. 85 (1996) 1017-1025; DOI: 10.1021/js950534b.

4. S. Baboota and S. P. Agarwal, Inclusion complexation of meloxicam with $\beta$-cyclodextrin, Ind. J. Pharm. Sci. 64 (2002) 408-411.

5. T. Loftsson, Increasing the cyclodextrin complexation of drugs and drug bioavailability through addition of water soluble polymers, Pharmazie 53 (1998) 733-740.

6. S. G. V. Kumar and D. N. Mishra, Preparation, characterization and in vitro dissolution studies of solid dispersion of meloxicam with PEG, J. Pharm. Soc. Jpn. 126 (2006) 657-664; DOI: 10.1248/ yakushi.126.657. 
H. A. El-Maradny et al.: Characterization of ternary complexes of meloxicam-HP $\beta C D$ and PVP or L-arginine prepared by the spraydrying technique, Acta Pharm. 58 (2008) 455-466.

7. M. Jug and M. Lacan-Becirevic, Multicomponent complexes of piroxicam with cyclodextrins and hydroxy propyl methyl cellulose, Drug Dev. Ind. Pharm. 30 (2004) 1051-1060; DOI: 10.1081/DDC-200040245 .

8. P. Mura, M. T. Faucci and G. P. Bettinetti, The influence of polyvinyl pyrrolidone on naproxen complexation with hydroxypropyl- $\beta$-cyclodextrins, Am. Ass. Pharm. Sci. 13 (2001)187-194.

9. K. P. R. Chowdry and S. V. Srinivas, Influence of hydrophilic polymers on celecoxib complexation with hydroxypropyl- $\beta$-cyclodextrins, AAPS PharmSciTech. 7 (2006) Article 79; DOI: 10.1208/pt070379.

10. L. Ribeiro, T. Loftsson, D. Ferreira and F. Veiga, Investigation and physicochemical characterization of vinpocetine-sulfobutyl ether beta cyclodextrin binary and ternary complexes, Chem. Pharm. Bull. 51 (2003) 914-922; DOI: 10.1248/cpb.51.914.

11. P. Mura, F. Maestrelli and M. Cirri, Ternary systems of naproxen with hydroxypropyl- $\beta$-cyclodextrins and amino acids, Int. J. Pharm. 260 (2003) 293-302; DOI: 10.1016/S0378-5173(03)00265-5.

12. P. Mura, G. P. Bettinetti, M. Cirri, F. Maestrelli, M. Sorrenti and L. Catenacci, Solid state characterization and dissolution properties of naproxen-arginine-hydroxypropyl beta-cyclodextrin ternary system, Eur. J. Pharm. Biopharm. 59 (2005) 99-106; DOI: 10.1016/j.ejpb.2004.05.005.

13. British Pharmacopoeia 2008, Vol. III, HSM, London 2008, pp. 2867.

14. T. Higuchi and K. A. Connors, Phase solubility techniques, Adv. Anal. Chem. Instrum. 4 (1965) 117-212.

15. P. Gupta and A. K. Bansal, Molecular interactions in celecoxib-PVP-meglumine amorphous system, J. Pharm. Pharmacol. 57 (2005) 303-310; DOI: 10.1211/0022357055597.

16. E. Redenti, L. Szente and J. Szejtli, Drug/cyclodextrin/hydroxy acid mutlicomponent systems. Properties and pharmaceutical applications, J. Pharm. Sci. 89 (2000) 1-8; DOI: 10.1002/(SICI)1520-6017(200001)89:1<1::AID-JPS1>3.3.CO;2-N.

17. X. Liu, H. Lin, J. Thenmozhiyal, S. Chan and O. Paul, Inclusion of acitretin into cyclodextrins: Phase solubility, photostability and physicochemical characterization, J. Pharm. Sci. 92 (2003) 2449-2457; DOI: 10.1002/jps.10495.

18. S. Baboota, M. Dhaliwal and K. Kohli, Physicochemical characterization, in vitro dissolution behaviour and pharmacodynamics studies of refecoxib-cyclodextrin inclusion compounds preparation and properties of refecoxib hydroxypropyl beta-cyclodextrin inclusion complex, Am. Ass. Pharm. Sci. 2 (2004) 1-25.

19. L. P. Ruan, B. Y. Yu, G. M. Fu and D. Zhu, Improving the solubility of ampelopsin by solid dispersion and inclusion complexes, J. Pharm. Biomed. Anal. 38 (2005) 457-464; DOI: 10.1016/j.jpba. 2005.01.030.

20. S. W. Jun, M. S. Kim, J. S. Kim, H. J. Park, S. Lee, Woo and S. J. Hwang, Preparation and characterization of simvastatin/hydroxypropyl $\beta$-cyclodextrin inclusion complex using supercritical antisolvent (SAS) process, Eur. J. Pharm. Biopharm. 66 (2007) 413-421; DOI: 10.1016/j.ejpb.2006. 11.013.

21. N. B. Naidu, K. P. Chowdary, K. V. Murthy, V. Satyanarayana, A. R. Hayman and G. Becket, Physicochemical characterization and dissolution properties of meloxicam cyclodextrin binary systems, J. Pharm. Biomed. Anal. 35 (2004) 75-86; DOI: 10.1016/j.jpba.2004.01.003.

22. C. P. Mora, M. Cirri, B. Allolio, F. Carli and P. Mura, Enhancement of dehydroepiandrosterone solubility and bioavailability and ternary complexation with $\alpha$-cyclodextrin and glycine, J. Pharm. Sci. 92 (2003) 2177-2184; DOI: 10.1002/jps.10485.

23. D. Laveneziana, R. Speranza, P. Raulli and G. Paredi, Ibuprofene-arginine in the managment of pain, Clin. Drug Invest. 11 (1996) 1-7; DOI: 10.2165/00044011-199600111-00003. 
H. A. El-Maradny et al.: Characterization of ternary complexes of meloxicam-HP $\beta C D$ and PVP or L-arginine prepared by the spraydrying technique, Acta Pharm. 58 (2008) 455-466.

$S A \check{Z} E T A K$

\section{Karakterizacija ternarnih kompleksa meloksikam-HP $\beta C D$ i PVP ili L-arginina pripravljenih metodom sušenja sprejom}

HODA A. EL-MARADNY, SANA A. MORTADA, OLA A. KAMEL i AHMED H. HIKAL

Ternarni kompleksi meloksikama (ME) (slabo vodotopljivi protuupalni lijek) s hidroksipropil- $\beta$-ciklodekstrinom (HP $\beta C D$ ) i/ili hidrofilnim polimerom polivinil pirolidonom (PVP) ili bazičnom aminokiselinom poput L-arginina, pripravljeni su metodom sušenja sprejom. Uspoređivan je utjecaj topljivosti, fizikalna svojstva i oslobađanje svakog ternarnog sustava ME-HP $\beta C D$ s PVP ili L-argininom s odgovarajućim binarnim sustavom ME-HP $\beta C D$. Tablete priređene iz ternarnog sustava ME-HP $\beta C D$-L-arginin uspoređene su s jednostavnim i komercijalno dostupnim tabletama. Pokusi topljivosti ukazuju na to

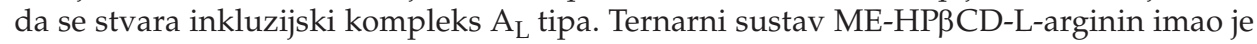
konstantu stabilnosti 30,3 puta veću nego binarni sustav ME-HPßCD, dok je ternarni sustav ME-HP $\beta C D-P V P$ imao tu konstantu uvećanu za samo 2,2 puta. Pripravljeni kompleksi karakterizirani su pomoću pretražne elektronske mikroskopije, diferencijalne pretražne kalorimetrije i infracrvene spektroskopije. Ternarni čvrsti kompleksi ukazali su na prisutnost snažnih interakcija između komponenata. Oslobađanje ME iz različitih ternarnih kompleksa bilo je veće značajno iz binarnih sustava. Tablete komprimirane iz ternarnog kompleksa ME-HP $\beta C D$-L-arginin imaju vrlo poboljšano oslobađanje ljekovite tvari u usporedbi s jednostavnim i komercijalno dostupnim tabletama.

Ključne riječi: meloksikam, hidroksipropil- $\beta$-ciklodekstrin, polivinil pirolidon, L-arginin, metoda sušenja sprejom

Department of Industrial Pharmacy, Faculty of Pharmacy, University of Alexandria

Amriya Pharmaceutical Industry, Alexandria, Egypt 